\title{
Ground motion prediction from nearest seismogenic zones in and around Greater Cairo Area, Egypt
}

\author{
Abd El-Aziz Khairy Abd El-Aal \\ National Research Institute of Astronomy and Geophysics, Helwan, Cairo, Egypt \\ Received: 6 October 2009 - Revised: 27 April 2010 - Accepted: 31 May 2010 - Published: 9 July 2010
}

\begin{abstract}
This paper reviews the likely source characteristics, focal source mechanism and fault patterns of the nearest effective seismogenic zones to Greater Cairo Area. Furthermore, $M_{\max }$ and ground accelerations related to the effective seismic events expected in future from those seismogenic zones are well evaluated. For this purpose, the digital waveform of earthquakes than $M_{\mathrm{L}}=3$ that occurred in and around Greater Cairo Area from 1997 to 2008 which have been recorded by the Egyptian National Seismological Network, are used to study source characterization, focal mechanism and fault pattern of the seismogenic zones around Greater Cairo Area. The ground motions are predicted from seismogenic zones to assess seismic hazard in the northeastern part of Greater Cairo, where three effective seismogenic zones, namely Abou Zabul, southeast Cairo trend and Dahshour area, have the largest effect to the Greater Cairo Area. The $M_{\max }$ was determined, based upon an empirical relationship between the seismic moment and the rupture length of the fault during the earthquake. The estimated $M_{\max }$ expected from Abou Zabul, southeast Cairo trend, Dahshour seismic sources are of $M_{\mathrm{w}}$ magnitudes equal to 5.4, 5.1, and 6.5, respectively. The predominant fundamental frequency and soil amplification characteristics at the area were obtained using boreholes data and in-situ ambient noise measurement.
\end{abstract}

\section{Introduction}

In Egypt, the population, archaeological sites and sensitive structures are concentrated within a narrow zone around the Nile valley that occupies only $1 \%$ of the total area of the country. Nevertheless, both the population and the newly developed areas in this zone are still growing rapidly. In

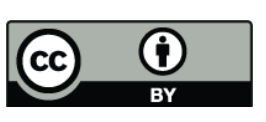

Correspondence to:

Abd El-Aziz Khairy Abd El-Aal

(dewaky@ nriag.sci.eg) general, buildings in Egypt are not designed to resist earthquakes, therefore relatively small events can be the source of huge socio-economic disasters. The event of 12 October 1992 is an example of a small but damaging earthquake in Egypt. Protection of strategic structures like nuclear power plants, dams and big populated cites, in Egypt, from all kinds of hazard, particularly earthquakes, is actually the essential mission of the seismologists and civil engineers in the present and the future.

The economic and social effects of earthquake disasters can be reduced through a comprehensive assessment of seismic hazard and risk for areas such as Egypt. Such a study leads to an increased public awareness, with a consequent upgrading of the existing buildings and engineering works as well as reliable earthquake-resistant designs for new structures. One of the most important seismic hazard assessment approaches is the deterministic seismic hazard. The deterministic seismic hazard analysis, in its most commonly used form, defines the seismic sources or seismogenic zones that might have an impact on the site of interest and then assesses the maximum possible earthquake magnitude $M_{\max }$ for each of these sources. By assuming each of these maximum earthquakes to occur at a location that places the earthquake at the minimum possible distance to the site, the ground motion is predicted, mostly, utilizing an empirical attenuation relation.

The ground motion amplification and high level of damages over soft soil and unconsolidated deposits have been shown to be responsible for increasing intensity than over the consolidated and hard sediments. From this point, it has long been understood that topographic and sedimentary deposits near the earth's surface can significantly amplify ground motion. Numerous other studies (Borcherdt, 1970; Aki, 1988; Field et al., 1992) have also demonstrated the ability of local geologic conditions to alter seismic motion. The first author that used ambient seismic noise (i.e. microseisms and microtremors) for estimating ground amplification was Kanai (1957). The main assumption is that the response of

Published by Copernicus Publications on behalf of the European Geosciences Union. 
sediments to noise sources is in some way related to that for incident seismic waves. Field and Jacob (1993) supported the theoretical meaning of the assumption. They computed the theoretical response of a horizontally stratified sedimentary layer to ambient noise sources represented as a random distribution (in time, space, and orientation) of impulsive point forces located on the Earth's surface. In the current research, the H/V Ratio, which was proposed by Nakamura (1989), is applied here to estimate the fundamental frequency and site amplification from microtremor records at the area of interest.

Finally, for the assessment of seismic hazard in terms of peak ground acceleration and the response spectra, the stochastic simulation technique proposed by Boore (2003) is used. The radiated energy is assumed to be evenly distributed over a specified duration. He assumed that the total spectrum of the motion at a site is formed from contributions from earthquake source, path site, site effect, and instrument. By separating the spectrum into these components, the models based on the stochastic method can be easily modified to account for specific situations or for improved information about particular aspects of the model. The prediction of ground motion or response amplitude as a function of earthquake magnitude and distance is of fundamental importance for the assessment of seismic hazard (Abd El-Aal, 2008, 2010).

Cairo is the capital of Egypt and the largest city in the Arab World, nicknamed "The City of a Thousand Minarets" for its preponderance of Islamic architecture. With a population of 17.2 million spread over $214 \mathrm{~km}^{2}$, Cairo is by far the largest city in Egypt as well as one of the most densely-populated cities in the world. With an additional 10 million inhabitants just outside the city, Cairo resides at the center of the largest metropolitan area in Africa and the eleventh-largest urban area in the world. Cairo is located on the banks and islands of the Nile River in the north of Egypt, immediately south of the point where the river leaves its desert-bound valley and breaks into two branches into the low-lying Nile Delta region. Referring to Cairo often means Greater Cairo Metropolitan Area (GCMA), which is composed of Cairo Governorate, part of Giza and Qaluobyia Governorates. Since May 2008 Greater Cairo has been divided into four new governorates: Cairo, Helwan, Giza Governorate and the 6 October Governorate. Cairo is a rapidly expanding city, which has led to many environmental problems. The draw factor of such important landmarks coupled with a very vibrant megalopolis with an estimated 17.2 million inhabitants makes GCMA more vulnerable to strong earthquakes. Hence, the prediction of expected ground-motions and their natural variability at the sites located at a given distance from an earthquake of a given magnitude is one of the most critical elements of any seismic hazard analysis for Egypt. For these reasons, the northeastern part of Greater Cairo Metropolitan area was selected to be our area of study (Fig. 1).

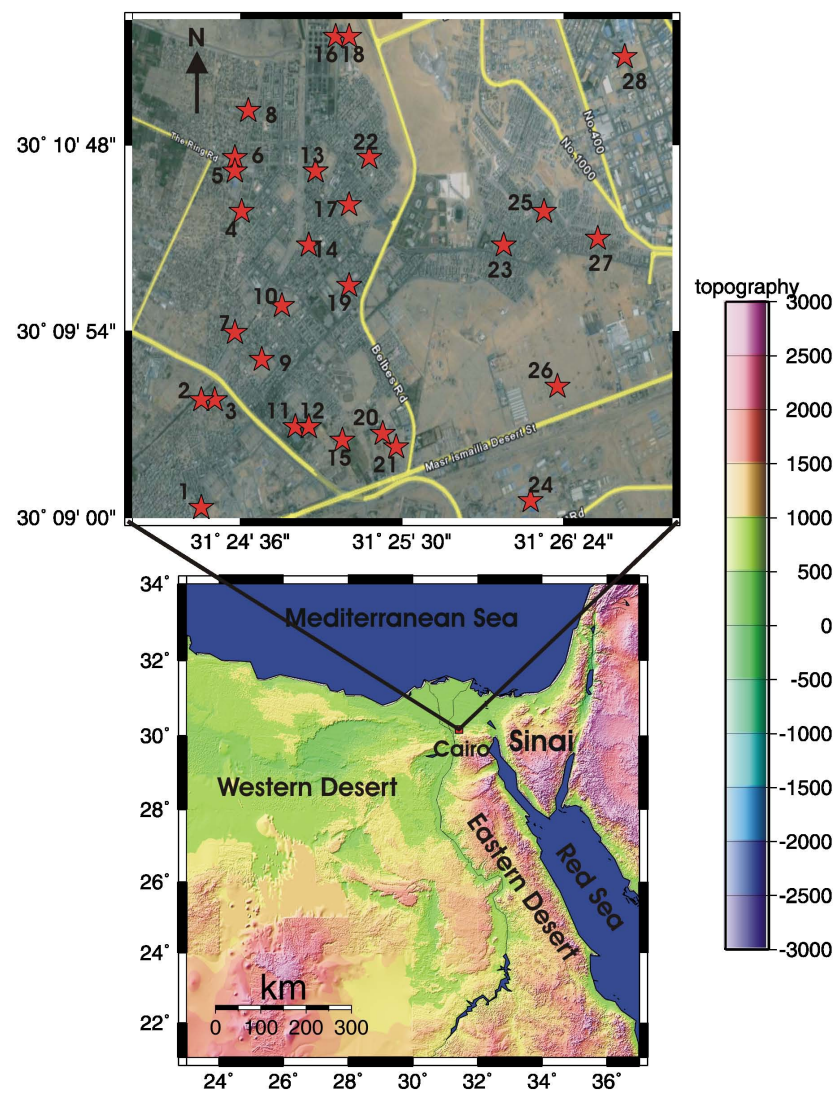

Fig. 1. Lower panel is a topographic map of Egypt. Upper panel is satellite image of the northeastern Greater Cairo Area. The red stars in upper panel map indicate to site No. of field seismic measurements.

\section{Overview of surface and structure geology}

The area of Greater Cairo is covered by sedimentary rocks of different formations belonging to the Eocene up to the Quaternary. The geology of the studied area was influenced by the history of the Nile Valley and the remnants of old settlement. Generally, the subsurface geological formations in the studied area are composed of three layers. The topmost layer is the soil layer with thickness ranging from $3 \mathrm{~m}$ to $40 \mathrm{~m}$ which is mainly composed of coarse soft sediments that were deposited in the Nile Canyon (Said, 1990). The basin from which these deposits were formed belongs to relatively old formations due to erosion from subsequent streams and rainfalls (Fig. 2). The second layer is composed mainly of shale with thickness ranging from $0.5 \mathrm{~m}$ to $3 \mathrm{~m}$. The third layer is the basalt layer with thickness ranging from $6 \mathrm{~m}$ to $60 \mathrm{~m}$. The area is highly deformed with different fault systems (EGSMA, 1983; Said, 1990). The most predominant ones are those of E-W and NW-SE trends. These trends are reported on both surface and subsurface. According to the Egyptian Geological Survey and Mining Authority (EGSMA, 1983), the area is affected mainly by the Gulf of 

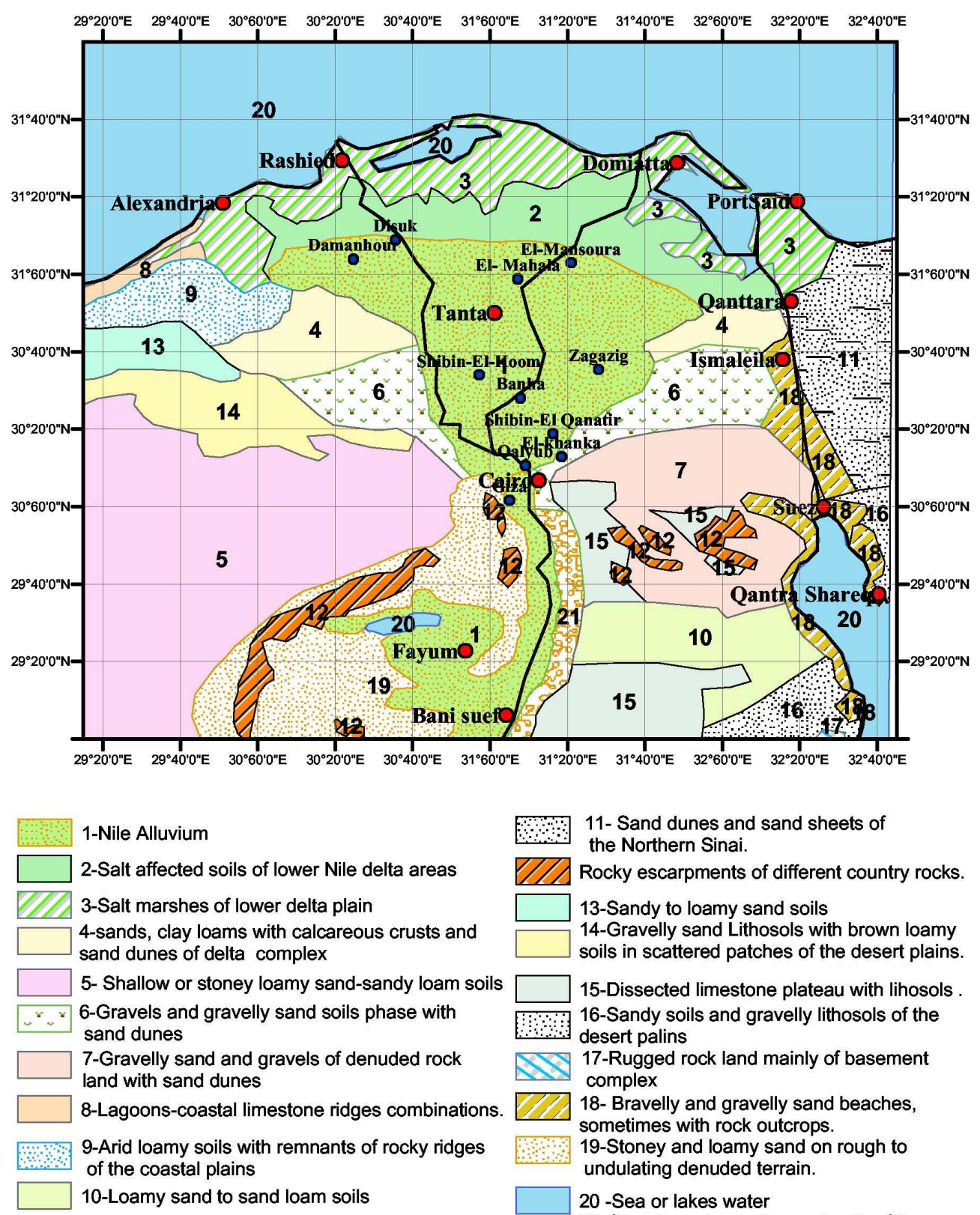

11- Sand dunes and sand sheets of
the Northern Sinai.
Rocky escarpments of different country rocks.
13-Sandy to loamy sand soils
14-Gravelly sand Lithosols with brown loamy
soils in scattered patches of the desert plains.
15-Dissected limestone plateau with lihosols
16-Sandy soils and gravelly lithosols of the
desert palins
17-Rugged rock land mainly of basement
complex
18- Bravelly and gravelly sand beaches,
sometimes with rock outcrops.
19-Stoney and loamy sand on rough to
undulating denuded terrain.
20 -Sea or lakes water
21-Gravels and gravelly sand soils of the
alluvial fans

Fig. 2. Map of Surface geology in and around Greater Cairo Area (scale 1:500 000, EGSMA, 1983).

Suez NW-SE fault trend represented by the Qatrani fault of normal type, and the Mediterranean E-W trend represented by Gabal El-Sheeb fault.

\section{Method}

It has been shown before a methodology (Abd El-Aal, 2010) for estimating the ground motion from the effective instrumental earthquakes (during the 1992, 1999, and 2002 Cairo earthquakes) to the northeastern Cairo Metropolitan Area. In the current work, a dynamic procedure is applied to calculate the PGAs for each $M_{\max }$ expected from the nearest seismogenic zones to the area of interest. For this purpose, the seismogenic zones, the fault patterns and focal mechanism of biggest recorded earthquakes in and around the area of interest, are estimated. The nonlinear least square inversion technique is used to calculate the source parameters for the selected earthquakes. The regression relationships between the earthquake magnitude and the fault parameters have been used to calculate the $M_{\max }$. Finally, the expected peak ground acceleration and response spectral for each $M_{\max }$ have been estimated. 


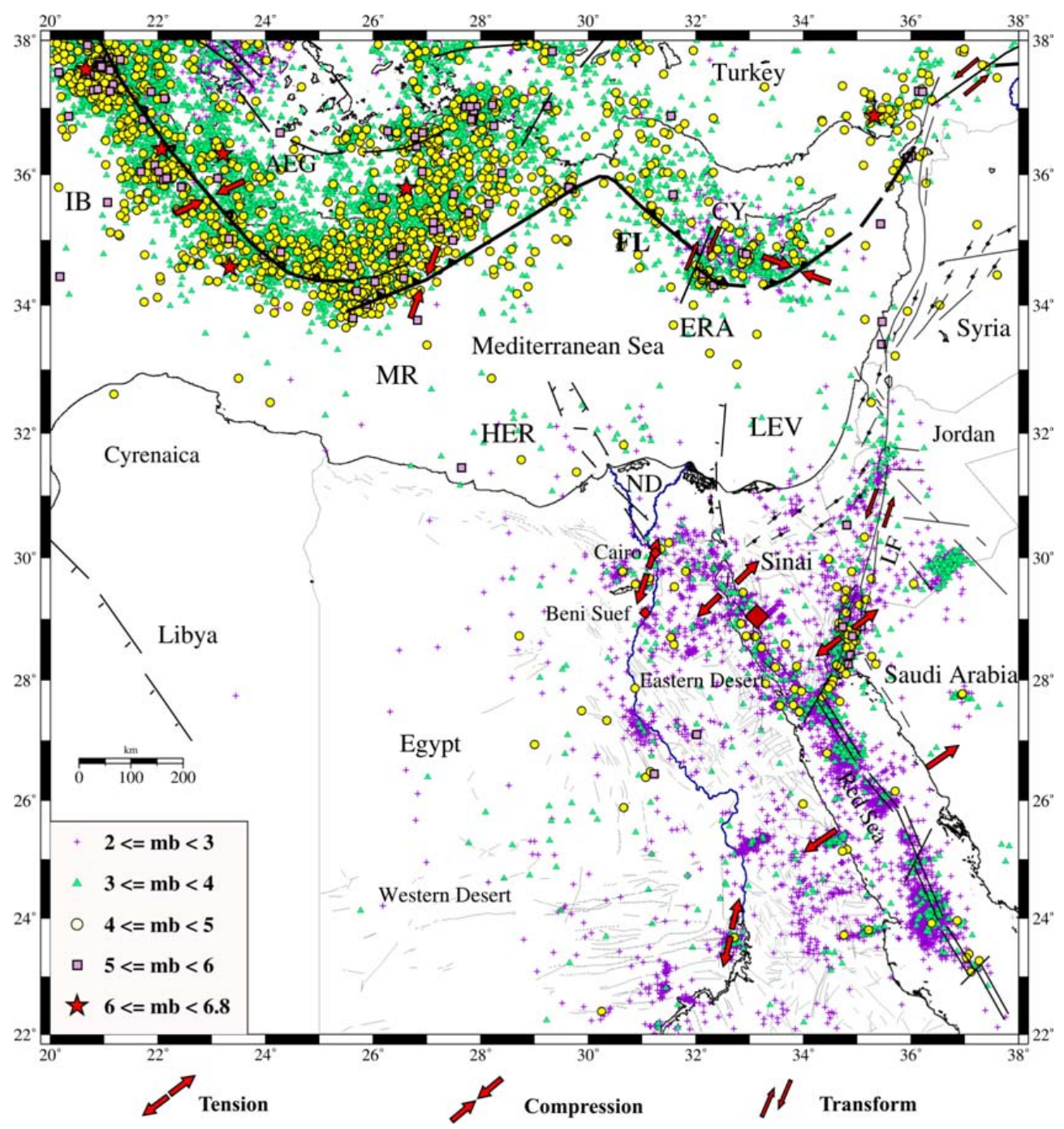

Fig. 3. Tectonic boundaries of the Eastern Mediterranean Region. Seismicity data $\left(2 \leq M_{\mathrm{b}}<6.8\right)$ was compiled (Abou Elenean and Hussein, 2008) from ENSN and NEIC (1997-2007). The following Acronyms represent: AEG - Aegean Sea; Al - Alexandria City; CY - Cyprus; ERA - Eratosthenes Seamount; FL - Florence; IB - Ionian Basin; MR - Mediterranean Ridge; LEV - Levantine Basin; LF - Levant Fault; ND - Nile Delta. Red diamond indicates the location of Abo Zenema area. After Abou Elenean et al. (2010).

\subsection{Overview of seismicity, seismotectoics, and seismic networks}

The study area undergoes severe extensional stress resulting from the regional forces of the neighboring plate boundaries including the African, Arabian and Eurasian plate margins, the Red Sea rifting system, and the Aqaba-Dead Sea fault system (Fig. 3). In addition, local tectonics structures of the Gulf of Suez and the Nile River affect the tectonic regime of northern Egypt. The major part of the tectonic deformation within Egypt is remote and takes place along the mentioned margins as revealed by the observed high rate of the seismic activity. Nevertheless, low to moderate seismic activity occurs along few E-W to NW-SE faults due to the partly transfer of deformation from these boundaries to activate these faults inland or due to the local stress (Abou Elenean and Hussein, 2008). Historically, greater Cairo was hit by a moderate size earthquake on 7 August 1847 (Fayum earthquake). This event had an intensity of VII in Fayum area (Maamoun et al., 1984). 85 people were killed, 62 were injured, 3000 houses and many mosques were destroyed. On 12 October 1992, a significant earthquake $\left(M_{\mathrm{b}}=5.8\right)$ occurred southwest of Cairo in the vicinity of the Dahshour region, about $25 \mathrm{~km} \mathrm{SW}$ of downtown Cairo at the coordinates $29.77 \mathrm{~N}, 31.07 \mathrm{E}$. The focal depth of this event was $23 \mathrm{~km}$. This event is the largest instrumentally recorded earthquake in Dahshour region. At least 561 people were killed, about 12192 injures were reported, more than 20000 people became homeless and 8300 buildings were damaged or destroyed in the Cairo area alone. The economic losses of this 
earthquake reached 4 billion US dollars. Hence, although this earthquake is classified as a small event $(M<6.0)$, it caused significant injuries, loss of life and damage to property. Significant damage was found mostly in adobe or non-reinforced masonry buildings and non-engineering reinforced concrete buildings (Japanese Expert Team, 1993). The damage was observed mostly in the buildings that were illegally constructed or constructed by poor construction work. The 12 October 1992 earthquake is the first disastrous event to have occurred in this region since the 1847 event, after a lapse of 145 years.

After the 12 October 1992 earthquake, the Egyptian government commissioned the National Research Institute of Astronomy and Geophysics, to organize and install the Egyptian National Seismological Network and the Egyptian Strong Ground Motion Network in an attempt to minimize the earthquake damages and to anticipate the future safe development of big strategic projects. The targets of these networks are the protection of the strategic buildings, and new cities, through monitoring local and regional seismic activity. The Egyptian National Seismological Network (ENSN) includes 60 seismic stations distributed in whole the area of Egypt and also involve one main center at Helwan city and five sub-centers at Burg El-Arab, Hurghada, Mersa Alam, Aswan and Kharga (Fig. 4). The sub-centers are recently connected to the main center using satellite communication. The digital data is extracted online from the remote telemetry stations, via radio, telephone lines and satellite communications by using seismic data analysis software (DAN and ATLAS programs). The received data is analyzed to calculate the earthquake parameters and the location of epicenter. Since 1996, the National Research Institute of Astronomy and Geophysics has installed strong motion instrument model IDS-3602A-16 Bit-Digital Accelerographs at different sites distributed all over Egypt (Fig. 4). On Tuesday, 28 December 1999, The Egyptian National Seismological Network (ENSN) recorded a small earthquake sequence that took place in northern Egypt, about $25 \mathrm{~km} \mathrm{NE}$ of Cairo. The $M_{\mathrm{b}}=4.5$ mainshock was felt throughout the great Cairo region and $12 \mathrm{~min}$ later was followed by a $M_{\mathrm{b}}=3.9$ aftershock and $4 \mathrm{~h}$ later by a $M_{\mathrm{b}}=3.6$ aftershock. Also on Saturday, 24 August 2002, greater Cairo was hit by a moderate earthquake with $M_{\mathrm{b}}=4.3$ and 3 min later was followed by an $M_{\mathrm{b}}=3.8$ aftershock. The events were recorded by the stations of the ENSN and Egyptian Strong Ground Motion Network.

\subsection{Digital and input data}

A set of digital and analog data have been used in this study. The digital data include both waveforms of earthquakes recorded by the ENSN in the period from 1997 to 2008, and digital data of microtremors measurements which have been conducted in the investigated area. On the other hand, the analog data includes all the well-log and boreholes which have been carried out by Egyptian General Organiza-

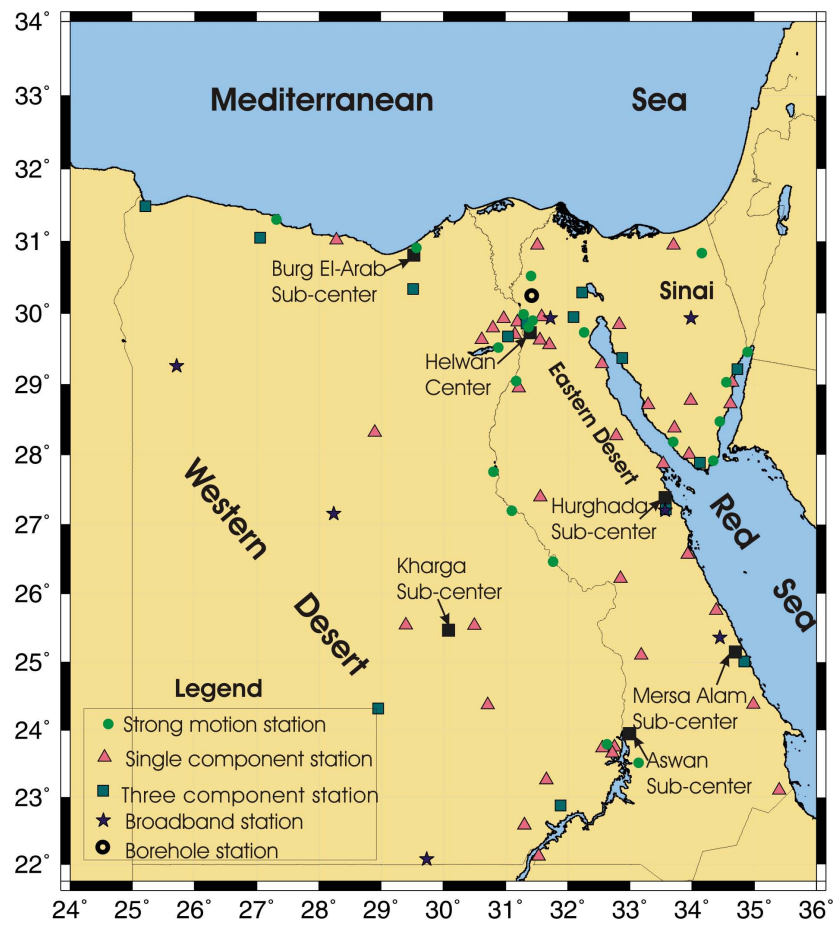

Fig. 4. The Egyptian National Seismic Network and the Egyptian Strong Ground Motion Network installed by National Research Institute of Astronomy and Geophysics.

tion for Physical Planning. The first set of data is used to determine focal mechanism of the effective events and for obtaining the source parameters using the inversion technique. Furthermore, the boreholes data with the microtremors data have been used to calculate the predominant frequencies and amplification factors in the studied area. Figure 5 illustrates examples of digital and analog data used in the current study.

Waveform data used in this study are from some stations belonging to the ENSN. All instruments are velocity sensors with a 24-bit digital recording system with sampling rate of 100 sample/s. The instrument response is flat, from 1.9 to $38 \mathrm{~Hz}$. The dynamic range is of about $124 \mathrm{~dB}$. For waveform analysis, parts of $\mathrm{P}$-wave and $\mathrm{S}$-wave of velocity records are used.

\subsection{Seismogenic zones in and around Greater Cairo Area}

The first step of the applied method is the definition of seismogenic zones in and around the area of interest. It involves the identification of earthquake generating faults and their preferred location (Reiter, 1991). In regions with difficult fault identification, the seismotectonic sources are identified as areas of grouped seismicity in which the earthquake activity and stress field orientation are assumed to be relatively uniform in terms of type and distribution of earthquakes. On the basis of earthquake distribution, Egypt can 
A

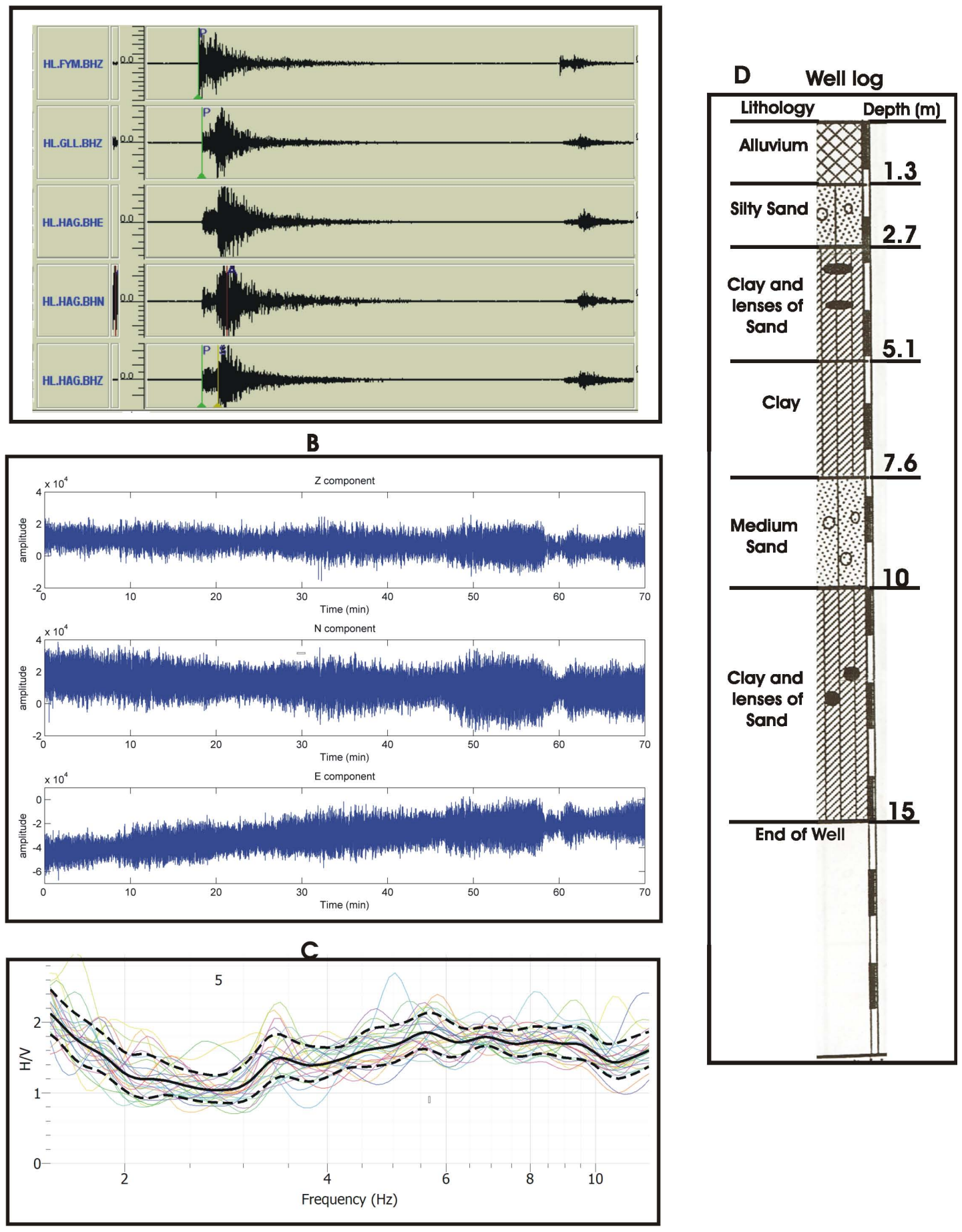

Fig. 5. Examples of digital and analog data used in the current study. Panel A is the digital waveform for the 24 August 2002 earthquake and its aftershock. Panel $\mathbf{B}$ is the digital waveforms of recorded background noise. Panel $\mathbf{C}$ is the $\mathrm{H} / \mathrm{V}$ result of recorded background noise at site 13. Panel $\mathbf{D}$ represents the analog data of borehole at site 9.

be divided into the two tectonic provinces: northern Egypt (north of $27^{\circ} \mathrm{N}$ ) and southern Egypt. The first province is more seismically active than the second province. It was also demonstrated that these provinces differ in stress patterns too
(Badawy, 2001). The spatial distribution of earthquake epicenters in Egypt suggests that the main activity occurs in the northern part of the Egyptian territory. The relative motion of the Sinai subplate with respect to the Arabian plate (Gulf 
Table 1. Focal mechanism parameters of the earthquakes with magnitude greater than $M_{\mathrm{L}} \geq 3$ which occurred in the effective sesimogenic zones in and around Greater Cairo Area.

\begin{tabular}{|c|c|c|c|c|c|c|c|}
\hline \multirow[t]{2}{*}{ Earthquake date } & \multicolumn{2}{|c|}{ Coordinates } & \multirow{2}{*}{$\begin{array}{l}\text { Magnitude } \\
\left(M_{\mathrm{L}}\right)\end{array}$} & \multicolumn{3}{|c|}{ Focal mechanism } & \multirow[t]{2}{*}{ Remarks } \\
\hline & Lat & Long & & Strike & Dip & Rake & \\
\hline 12 Oct 1992 & 29.77 & 31.07 & 5.8 & 161 & 58 & -40 & \\
\hline 28 Dec 1999-M & 30.29 & 31.45 & 4.5 & 137 & 72 & -39 & Mainshock \\
\hline 28 Dec 1999-AF1 & 30.25 & 31.5 & 3.1 & 130 & 70 & -35 & Aftershock \\
\hline 28 Dec 1999-AF2 & 30.26 & 31.44 & 3.3 & 140 & 75 & -37 & Aftershock \\
\hline 29 Jun 2000 & 29.53 & 31.6 & 4 & 126 & 45 & -64 & \\
\hline 3 Oct 2000 & 29.67 & 31.1 & 3.4 & 132 & 46 & -47 & \\
\hline 9 Dec 2000 & 30.28 & 31.09 & 3.4 & 103 & 37 & -129 & \\
\hline 24 Feb 2001 & 29.67 & 31.07 & 3.5 & 130 & 75 & -72 & \\
\hline 12 Jun 2001 & 29.66 & 31.12 & 4.1 & 115 & 70 & -60 & \\
\hline 17 Dec 2001 & 29.57 & 30.88 & 4.3 & 82 & 73 & -145 & Mainshock \\
\hline 24 Aug 2002-M & 30.14 & 31.35 & 4.3 & 89 & 40 & -87 & Aftershock \\
\hline 24 Aug 2002-AF1 & 30.24 & 31.32 & 3.8 & 103 & 37 & -129 & \\
\hline 27 Jun 2003 & 29.65 & 31.14 & 3 & 170 & 45 & -26 & \\
\hline 25 Mar 2004 & 30.54 & 31.74 & 3.7 & 323 & 48 & -65 & \\
\hline 28 Nov 2004 & 30.34 & 31.67 & 3.5 & 310 & 65 & -90 & \\
\hline 15 May 2005 & 30.08 & 31.42 & 3.1 & 234 & 37 & -126 & \\
\hline 7 Jul 2005 & 29.88 & 31.84 & 4.2 & 125 & 84 & 139 & \\
\hline 31 Jul 2005 & 29.67 & 31.13 & 4.3 & 92 & 30 & -86 & \\
\hline 30 Oct 2007 & 29.78 & 31.81 & 4 & 127 & 67 & -59 & \\
\hline 21 Jun 2008 & 29.78 & 30.64 & 4 & 77 & 76 & -139 & \\
\hline
\end{tabular}

of Aqaba and Dead Sea) and to the African plate (Gulf of Suez) represents the main source of active tectonics and seismic activity. However, according to the fault patterns and focal mechanism for the earthquakes recorded in and around the studied area, three seismogenic zones have been recognized which they have the biggest effect to the area. Table 1 lists the focal mechanism parameters for earthquakes with $M_{\mathrm{L}} \geq 3$ which occurred in the defined seismogenic zones in and around the area of interest. For more details about the seismic sources around Greater Cairo Area see Abd ElAal (2010).

\subsubsection{Fault patterns and focal mechanism of seismogenic zone 1}

The area, in which the epicenter of 28 December 1999 earthquake and its aftershocks located (Abou Zabul area), is considered as a separate seismic zone depending on fault and stress pattern and focal mechanism of recent earthquakes occurred in this area (Fig. 6). Along this trend, small to moderate historical and recent earthquakes have been observed (Fig. 7). It is clear that the Cairo region has suffered not only from interplate earthquakes but also from inland seismic dislocations. The most active inland dislocation is the Dahshour area ( $25 \mathrm{~km}$ southwest of Cairo) and Abou Zabul area. The present-day stress field, estimated from several focal mechanisms and borehole breakouts shows a transtensional stress regime with a tension axis about N-S to NE-SW in northern Egypt. Three fault trends, E-W, NW-SE, and NE-SW, affect the epicentral area. All these faults are normal faults. The stresses which created the structure in the Abou Zabul area were tensional rather than compressional. According to Maamoun and Allam (1980), the presence of earthquake epicenters in Nile, just in the front of the mouth of Alexandria Canyon may indicate that the course of the canyon is affected by faulting extends in NW-SE direction (Abdel-Fattah and Badawy, 2004).

According to the focal mechanism and radiation pattern of the mainshock and aftershocks of 28 December 1999 earthquake (Fig. 6), the rupture direction propagated toward $\mathrm{S} 137^{\circ} \mathrm{E}$ with an averaged rupture velocity around $0.75 \mathrm{~V}_{\mathrm{s}}$. The result obtained for rupture direction is in agreement with one of the nodal planes of focal mechanism. From the rupture directivity analysis, focal mechanism and geological evidence it follows that the investigated event reflects a reactivation of a NW-SE Oligocene deep-seated normal faulting with sinistral movement with fault radius of $344 \mathrm{~m}$, fault length $1460 \mathrm{~m}$.

\subsubsection{Fault patterns and focal mechanism of seismogenic zone 2}

The closest seismogenic zone to the study area is the SuezCairo shear zone. This trend is the major active trend in Egypt and extends along the northern Red Sea, Gulf of Suez, 

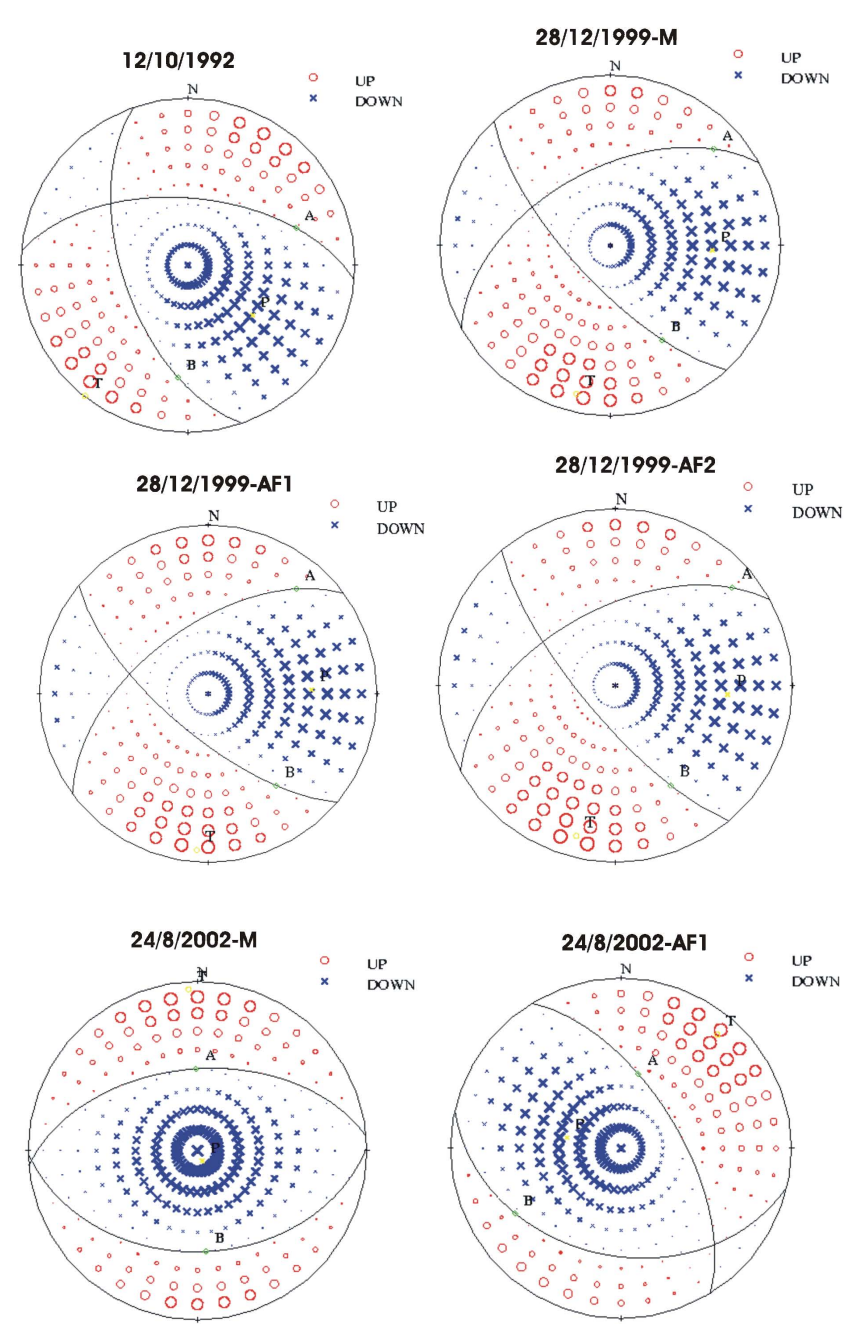

Fig. 6. Focal mechanism and radiation pattern of: 1) 28 December 1999 earthquake and its aftershocks (seismogenic zone 1), $24 \mathrm{Au}-$ gust 2002 earthquake and its aftershock (seismogenic zone 2), and 3) 12 October 1992 earthquake (seismogenic zone 3). Focal mechanism based on the polarities of $\mathrm{P}$-wave and lower hemisphere equal area projection is used.

and is characterized by the occurrences of shallow, micro, small, moderate and large earthquakes (Fig. 7). The $24 \mathrm{Au}-$ gust 2002 earthquake is located in this active zone. The predominant factor in terms of seismic hazard is generally related to the occurrence of moderate size earthquakes at short distances rather than large earthquakes that are known to occur at larger distances along the northern Red Sea, the Gulf of Suez and the offshore Mediterranean region (e.g., the Alexandria offshore earthquake in 1955; $M_{\mathrm{w}}=6.8$; the Shadwan earthquake in 1969; $M_{\mathrm{w}}=6.9$; as well as the Gulf of Aqaba earthquake in 1995; $M_{\mathrm{w}}=7.3$ ). The activity along this trend is mainly attributed to the Red Sea rifting as well as to several active faults. So the seismic activity of this rift is associated with the deep axial trough in its central and south-

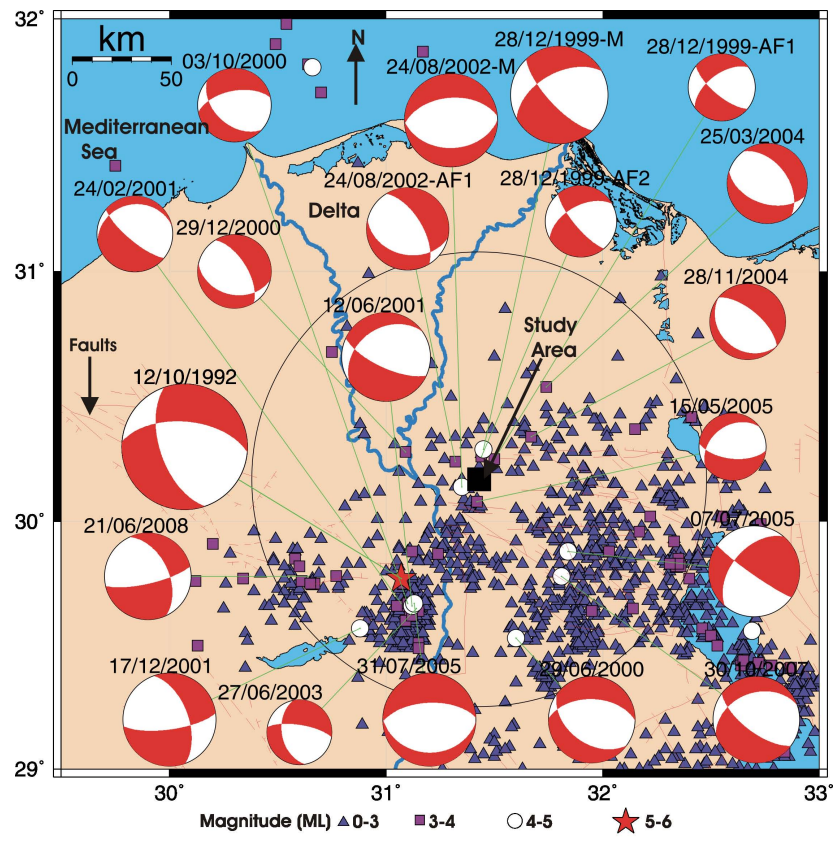

Fig. 7. The closest seismogenic zones in and around Greater Cairo Area. Earthquakes recorded by Egyptian National Seismic Network from 1997 to 2008. Black square represents the location of studied area. Focal mechanism of the earthquakes greater than $M_{\mathrm{L}}>3$ is presented with lower hemisphere projection and dark quadrant denotes compression.

ern parts (Kebeasy, 1990). The seismic activity is migrated northerly toward the region of Jubal Island at the entrance of the Gulf of Suez, where the activity tends to follow the two different structural trends of the Aqaba-Levant zone and the Gulf of Suez zone. It is clear that the high rate of seismicity in the southern end of the Gulf of Suez is related to the crustal movements among the Arabian plate, African plate and the Sinai subplate, as a result of the opening of the Red Sea extension in the Gulf of Suez and the left-lateral strikeslip motion of the Gulf of Aqaba. Daggett et al. (1986) indicated that although the southern end of the Gulf of Suez is seismically active, the activity does not extend along the length of the gulf. So there is a seismic gap in the Gulf of Suez.

Figure 7 shows few small-moderate events with magnitudes up to $M_{\mathrm{L}}=4.5$ in this active area. Depending on the focal mechanism and fault pattern (Figs. 6 and 7), the seismic activity of this zone is related to the faults trending NW-SE that parallel to the Gulf trend and that perpendicular to the gulf (NE-SW). Farther southeast a new source of seismic activity is located to the southeast of Beni Suef City. This zone is characterized by small to moderate activity. The focal mechanism of one event in that area reflects normal fault, trending NW-SE with slight strike slip component. 


\subsubsection{Fault patterns and focal mechanism of seismogenic zone 3}

On 12 October 1992, a damaging earthquake of magnitude $M_{\mathrm{b}}=5.8$, hit the Capital of Egypt. This event took place in Dahshour area, $25 \mathrm{~km}$ to the southwest of Cairo City. Many aftershocks followed the mainshock. The similarity between the mechanisms as well as the spatial distribution of the geological faults around Cairo suggest seismic activity along the extension of the stress field of the Red Sea rift system to the area around the city of Cairo. This situation affects the level of seismic hazard in the Cairo area.

The seismogenic zone, in which the 12 October 1992 earthquake was located, is considered as one of the most active seismogenic zones to greater Cairo metropolitan area. According to the temporal distribution of the last decade reported seismicity in Northern Egypt, Abou Elenean (1997) used the epicentral distribution, seismicity level and the similarity of focal mechanisms, considered the area southwest of Cairo (Dahshour area) as a seismogenic zone. Tectonically, the faults of this area are trending E-W, parallel to the Mediterranean trend, or NW-SW, parallel to the Gulf of Suez trend. The NW-SE and E-W directions accord with the surface features, which appeared immediately after the occurrence of 1992 earthquake with a fault length $13.8 \mathrm{~km}$ (Figs. 6 and 7). In the Dahshour seismogenic zone, there are three main lithological categories that can be distinguished: 1) unconsolidated Quaternary sediments in Fayoum basin, the Nile Delta and along the Nile River; 2) Limestone and clastic sediments of Paleogene, and 3) Neogene formation which consists mainly of clastic sediments of Miocene age, covering most of the northern part of the western desert.

\subsection{Source parameters and nonlinear least square inversion technique}

Several workers have attempted to determine source parameters for small and moderate earthquakes and suggested that fairly complete source information can be extracted from a single seismic station given certain conditions. Source parameters are very useful in ground motion evaluation and in the assessment of seismic hazard. In the current work, the nonlinear least square inversion technique has been used to estimate the dynamic source parameters for three effective events from seismogenic zones around the studied area. Seismic moment, size of the rupture plane, source dislocation and stress drop have been estimated using the S-wave displacement spectrum. The instrument response from the original seismograms was removed to obtain true ground motion (displacement). At each station the vertical, N-S and E-W components are rotated to great circle projection to get radial and transverse components. The S-wave spectrum is computed from the transverse component and corrected for attenuation and path effects using the average attenuation relation
Table 2. Modelling parameters for the application of the source parameters, Mmax and PGA estimation from different seismogenic zones in and around Greater Cairo Area.

\begin{tabular}{lccc}
\hline & $\begin{array}{c}\text { Seismogenic } \\
\text { zone 1 }\end{array}$ & $\begin{array}{c}\text { Seismogenic } \\
\text { zone } 2\end{array}$ & $\begin{array}{c}\text { Seismogenic } \\
\text { zone 3 }\end{array}$ \\
\hline $\begin{array}{l}\text { Density }(\rho) \\
\left(\mathrm{g} / \mathrm{cm}^{3}\right)\end{array}$ & 2.71 & 2.70 & 2.72 \\
$\begin{array}{l}\text { P-wave velocity }\left(V_{\mathrm{p}}\right) \\
(\mathrm{km} / \mathrm{s})\end{array}$ & 6.54 & 6.51 & 6.59 \\
$\begin{array}{l}\text { S-wave velocity }\left(V_{\mathrm{s}}\right) \\
(\mathrm{km} / \mathrm{s})\end{array}$ & 3.70 & 3.69 & 3.72 \\
$\begin{array}{l}\text { The free surface } \\
\text { amplification }\left(S_{\mathrm{a}}\right)\end{array}$ & 2 & 2 & 2 \\
$\begin{array}{l}\text { Radiation pattern } \\
\text { coefficient }(\Theta)\end{array}$ & 0.52 & 0.52 & 0.52 \\
$\begin{array}{l}\text { Kappa operator }(\kappa) \\
Q(f)\end{array}$ & 0.035 & 0.032 & 0.033 \\
Geometric spreading & $1 / 13.2$ & $1 / 7.7$ & $1 / 46.2$ \\
\hline
\end{tabular}

for greater Cairo. The amplitude level at low frequencies is constant, while it decays for higher frequencies with decay constant as $\omega^{2}$.

The displacement spectrum is approximated by two straight lines, the first represents a constant amplitude level $u_{\mathrm{o}}$ at low frequencies and the second is the approximation of decay spectrum at higher frequencies. The intersection of these two straight lines gives the corner frequency $f_{\mathrm{c}}$. The source parameters are computed using $u_{\mathrm{o}}$ and $f_{\mathrm{c}}$ applying the circular source model of Brune $(1970,1971)$. Using this model and Hanks and Wyss (1972), the relation between seismic moment $M_{0}$ and $u_{\mathrm{o}}$ with average S-wave velocity is given as:

$M_{0}=4 \pi r \rho\left(V_{\mathrm{s}}\right)^{3} \tilde{n} u_{\mathrm{o}} / \Theta S_{\mathrm{a}}$

where $r$ is the hypocentral distance, $V_{\mathrm{s}}$ is shear wave velocity, $\rho$ is the density, $u_{\mathrm{o}}$ is low frequency spectral level, $\Theta$ is averaged radiation pattern and $S_{\mathrm{a}}$ is the free surface amplification (Table 2).

The source radius $(R)$ depends on $f_{\mathrm{c}}$, and the relation is as follows:

$R=V_{\mathrm{s}} K_{\mathrm{s}} / 2 \pi f_{\mathrm{cs}}$

where $K_{\mathrm{s}}$ is model constant, and $f_{\mathrm{cs}}$ is corner frequency for the shear wave.

The area of the rupture plane is calculated after obtaining the radius of the source $(R)$ as

$A=\pi R^{2}$

The fault displacement $(D)$ or average source dislocation is directly proportional to the seismic moment $\left(M_{0}\right)$ and 
Table 3. Source parameters of the effective earthquakes from different seismogenic zones.

\begin{tabular}{|c|c|c|c|c|c|c|c|c|c|c|c|c|c|}
\hline \multirow{2}{*}{$\begin{array}{l}\text { Seismo- } \\
\text { genic } \\
\text { zone }\end{array}$} & \multirow{2}{*}{$\begin{array}{l}\text { Earthquake } \\
\text { date }\end{array}$} & & \multicolumn{5}{|c|}{ Coordinates } & \multicolumn{6}{|c|}{ Source parameters } \\
\hline & & & Lat & Long & $k$ & $\begin{array}{l}u_{\mathrm{O}} \\
(\mathrm{cm} \mathrm{s})\end{array}$ & $\begin{array}{l}f_{\mathrm{cs}} \\
(\mathrm{Hz})\end{array}$ & $\begin{array}{l}\Delta \sigma \\
\text { (bar) }\end{array}$ & $\begin{array}{l}M_{0} \\
\text { (dyne-cm) }\end{array}$ & $M_{\mathrm{w}}$ & $\begin{array}{l}R \\
(\mathrm{~km})\end{array}$ & $\begin{array}{l}A \\
\left(\mathrm{~km}^{2}\right)\end{array}$ & $M_{\max }$ \\
\hline \multirow[t]{3}{*}{1} & 28 Dec 1999 & Mainshock & 30.29 & 31.45 & 0.019 & $43 \times 10^{-4}$ & 1.16 & 3.71 & $7.848 \times 10^{22}$ & 4.5 & 2.10 & 13.85 & 5.4 \\
\hline & & Aftershock & 30.25 & 31.50 & 0.018 & $20 \times 10^{-6}$ & 1.80 & 0.064 & $3.65 \times 10^{20}$ & 3.0 & 1.35 & 5.75 & \\
\hline & & Aftershock & 30.26 & 31.44 & 0.018 & $40 \times 10^{-6}$ & 1.60 & 0.091 & $7.31 \times 10^{20}$ & 3.2 & 1.52 & 7.28 & \\
\hline \multirow[t]{2}{*}{2} & 24 Aug 2002 & Mainshock & 30.14 & 31.35 & 0.015 & $28 \times 10^{-4}$ & 1.48 & 2.50 & $2.55 \times 10^{22}$ & 4.2 & 1.64 & 8.50 & 5.1 \\
\hline & & Aftershock & 30.24 & 31.32 & 0.015 & $50 \times 10^{-5}$ & 1.58 & 0.54 & $4.56 \times 10^{21}$ & 3.7 & 1.54 & 7.46 & \\
\hline 3 & 12 Oct 2002 & Mainshock & 29.77 & 31.07 & 0.025 & $22 \times 10^{-2}$ & 0.29 & 4.45 & $6.02 \times 10^{24}$ & 5.8 & 8.39 & 221.60 & 6.5 \\
\hline
\end{tabular}

inversely proportional to the rigidity and area of the rupture plane:

$D=M_{0} / \mu A$

where $\mu$ is the shear modulus.

The stress drop is determined using the relationship:

$\Delta \sigma=7 M_{0} / 16 R^{3}$

In turn, $M_{0}$ (expressed in $\mathrm{Nm}$ ) is directly related to moment magnitude $M_{\mathrm{W}}$ by the Hanks and Kanamori (1979) formula:

$M_{\mathrm{w}}=2 / 3 \log M_{0}-10.7$

The source parameters, such as the seismic moment $\left(M_{0}\right)$, the fault radius $(R)$, the stress drop $(\Delta \sigma)$, and the moment magnitude $\left(M_{\mathrm{W}}\right)$ were determined for the three studied main shocks occurred recently (12 October $1992, M_{\mathrm{b}}=5.8 ; 28$ December $1999, M_{\mathrm{b}}=4.5$ and its aftershocks; 24 August 24, 2002, $M_{\mathrm{b}}=4.3$ and its aftershocks) from the analysis of the $\mathrm{S}$-wave amplitude displacement spectra. A MATLAB code was written to estimate these parameters. The analyzed data for main shocks of 1999 and 2002 earthquakes coming from ten short-period stations installed in hard rock sites and characterized by a good signal to noise ratio. They were located within epicentral distances ranging from 30 to $200 \mathrm{~km}$. Data for the 1992 earthquake came from two broadband stations. Table 3 illustrates the estimated model parameters obtained from spectral analysis using nonlinear least square inversion technique.

\section{5 $M_{\max }$ estimation}

Seismic hazard analyses, both probabilistic and deterministic, require an assessment of the future earthquake potential in a region. Specifically, it is often necessary to estimate the size of the largest earthquakes that might be generated by a particular fault or earthquake source. It is rare, however, that the largest possible earthquakes along individual faults have occurred during the historical period. Thus, the future earthquake potential of a fault is commonly evaluated from estimates of fault rupture parameters that are, in turn, related to earthquake magnitude.

The methods available for estimating $M_{\max }$ can be classified according to four procedures: 1 ) in the case of the presence of paleoseismological studies, the results of these studies indicate the maximum magnitude; 2) when the seismic history is available, the maximum magnitude is estimated using the statistical procedure proposed by Kijko (2004); 3) when consistent data regarding fault type and its total length were available, it is assumed that portions from $20 \%$ to $40 \%$ of the total fault length could rupture in one earthquake and then the maximum magnitude is estimated; 4) in any remaining case, the maximum magnitude is estimated by adding 0.5 magnitude unit to the largest known magnitude in the zone.

It has been known for some time that earthquake magnitude may be correlated with rupture parameters such as length and displacement. Accordingly, paleoseismic and geologic studies of active faults focus on estimating these source characteristics. For example, data from geomorphic and geologic investigations of faults may be used to assess the occurrence time of past earthquakes, the amount of displacement per event, and the segmentation of the fault zone (e.g., Schwartz and Coppersmith, 1986; Schwartz, 1988; Coppersmith, 1991). To translate these source characteristics into estimates of earthquake size, relationships between rupture parameters and the measure of earthquake size, typically magnitude, are required. Numerous published empirical relationships relate magnitude to various fault rupture parameters. Typically, magnitude is related to surface rupture length as a function of slip type. Additional relationships that have been investigated include displacement versus rupture length, magnitude versus maximum surface displacement, magnitude versus total fault length, and magnitude versus surface displacement times surface rupture length (Ohnaka, 
1978; Slemmons, 1977, 1982; Acharya, 1979; Bonilla et al., 1984; Slemmons et al., 1989). Other studies relate magnitude and seismic moment to rupture length, rupture width, and rupture area as estimated from the extent of surface deformation, dimensions of the aftershock zone, or earthquake source time functions (Hanks and Wyss, 1972: Hanks and Kanamori, 1979; Reiter, 1990; Wells and Coppersmith, 1994).

In this study, the procedure 3 has been used for estimating the maximum magnitude $M_{\max }$ for each seismic zone. The relationship between moment magnitude $M_{\mathrm{w}}$ (Hanks and Kanamori, 1979) with the $\log$ of the rupture area $A$ to the largest events (though with a different offset than is generally used for smaller events, Wells and Coppersmith, 1994) could be written as:

$M_{\max }=\log A+4.2$

For an infinitely long rupture with a finite width $W$, and a constant stress drop, slip should scale as $W$, so moment scales with area $A$ as AW, so moment magnitude which is $2 / 3$ of the $\log$ of the moment should scale with $A$ as $2 / 3 \log A$ for fixed $W$. Then to get the $\log A$ magnitude area relationship in Eq. (7) for fixed $W$ we would need stress drop $\Delta \sigma$ to scale as $\Delta \sigma \sim A^{1 / 2}$. The second scaling relation, the Hanks-Bakun relation (Hanks and Bakun, 2002), used a bilinear scaling relationship of:

$$
\begin{array}{ll}
M_{\max }=\log A+3.98 & A \leq 557 \mathrm{~km}^{2} \\
M_{\max }=4 / 3 \log A+3.07 & A>557 \mathrm{~km}^{2}
\end{array}
$$

where $A$ is the total ruptured area that can be calculated by the relation of Fukao and Kikuchi (1987):

$A=\pi\left(V_{\mathrm{r}} t / 2\right)^{2}$

where $V_{\mathrm{r}}$ is the rupture velocity (typically $V_{\mathrm{r}}$ is in the range $0.7-0.9 V_{\mathrm{s}}, V_{\mathrm{S}}$ being the shear wave velocity), $t$ represents the rupture duration. $V_{\mathrm{r}} t / 2$ represents the fault radius $\left(r_{0}\right)$. Moreover, $25 \%$ as a maximum portion of the fault length that can be ruptured in one earthquake is chosen in this study and this choice is in good agreement with the results from the paleo-seismological studies (Maamoun et al., 1984). The $M_{\max }$ expected from seismogenic zones 1, 2, and 3 are 5.4, 5.1, and 6.5, respectively (Fig. 8).

\subsection{Synthetic earthquake model and peak ground acceleration calculations for $M_{\max }$}

Evaluation of the seismic hazard at the investigated sites requires the prediction of the strong ground motion that will be generated by the potentially dangerous earthquakes. For the area having limited seismic record, synthetic ground motion models is the alternative (as the study area lacks ground motion records). Modeling of strong motion helps to estimate future hazard of the region and study the local soil effects in local scale. For the greater Cairo metropolitan

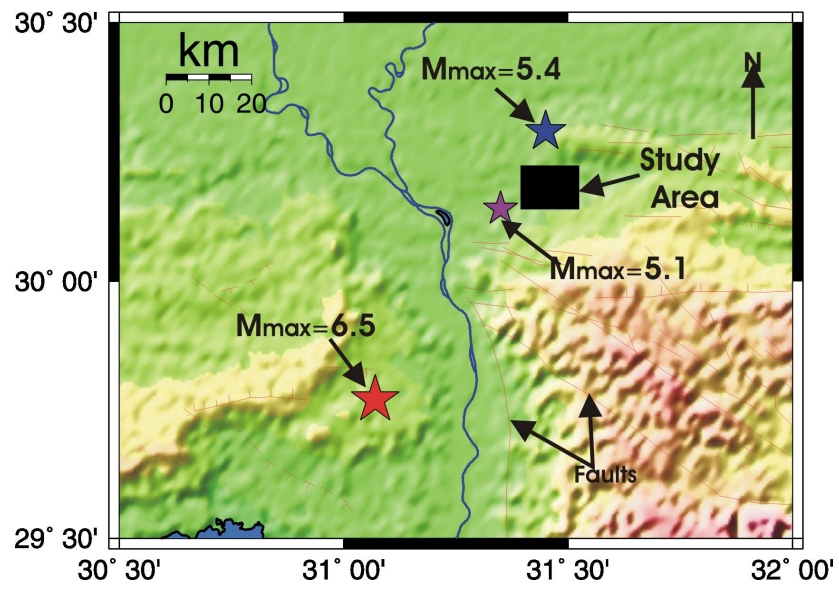

Fig. 8. Location map of $M_{\max }$ expected from effective seismogenic zones in and around Greater Cairo Area.

area many authors have developed ground motion attenuation relations based on the statistically simulated seismological model. The seismological model by Boore (1983) is used for generation of synthetic acceleration-time response (Atkinson and Boore, 1995). The synthetic ground motion and spectral acceleration at rock level for 3 seismic sources are developed by considering expected magnitude and hypocentral distance. A simple and powerful method for estimating ground motions is based on the assumption that, the amplitude of ground motion at a site can be specified in a deterministic way, with a random phase spectrum modified, such that the motion is distributed over a duration related to the earthquake magnitude and distance from source. This technique is known as the stochastic simulation of high frequency shear wave ground motion (Boore 2003), where the energy is distributed randomly over the duration of the source. The total spectrum of the motion at a site is expressed as the contributions from the earthquake source $(\mathrm{E})$, path $(\mathrm{P})$, site (G) and instrument (I). For more comprehensive summary about the method, refer to the work of (Boore, 2003; Abd El-Aal, 2008, 2010). In the current work, the PGA predicted from $M_{\max }$ for each seismogenic zone is calculated. The procedure includes 3 input parameters, source characterization, attenuation parameters, and site amplification factors. The input source and attenuation parameters are listed in Table 2, some of these parameters were collected from ElHadidy (1995) and Moustafa (2002), the source parameters and $M_{\max }$ are calculated from inversion technique (Table 3), while the site amplification factors $A_{0}$ (Table 4 ) are estimated for microtremor survey which has been conducted in the investigated area. The horizontal to vertical $(\mathrm{H} / \mathrm{V})$ spectral ratio technique has applied to detect the fundamental frequency and amplification factors at the sites of ambient noise recordings for the investigated area. Noise measurements are acquired at 27 sites for one hour of continuous recording with a sampling rate of $100 \mathrm{~Hz}$. Then, these data are processed 
Table 4. The estimated A0 and F0 and the PGA predicted from the effective seismogenic zones at the investigated sites in the area of interest.

\begin{tabular}{|c|c|c|c|c|c|c|c|}
\hline Site & Long & Lat & $A_{0}$ & $\begin{array}{l}F_{0} \\
(\mathrm{~Hz})\end{array}$ & $\begin{array}{c}\text { PGA from } \\
\text { seismic source } 1 \\
\operatorname{gal}\left(\mathrm{cm} / \mathrm{s}^{2}\right)\end{array}$ & $\begin{array}{c}\text { PGA from } \\
\text { seismic source } 2 \\
\operatorname{gal}\left(\mathrm{cm} / \mathrm{s}^{2}\right)\end{array}$ & $\begin{array}{c}\text { PGA from } \\
\text { seismic source } 3 \\
\mathrm{gal}\left(\mathrm{cm} / \mathrm{s}^{2}\right)\end{array}$ \\
\hline 1 & 31.40561 & 30.1504 & 3.2 & 5.31 & $5.85 \mathrm{E}+01$ & $8.92 \mathrm{E}+01$ & $2.65 \mathrm{E}+01$ \\
\hline 2 & 31.40721 & 30.15913 & 3.45 & 1.7 & $6.30 \mathrm{E}+01$ & $9.62 \mathrm{E}+01$ & $2.86 \mathrm{E}+01$ \\
\hline 3 & 31.408 & 30.159 & 3.23 & 4.8 & $5.90 \mathrm{E}+01$ & $9.01 \mathrm{E}+01$ & $2.68 \mathrm{E}+01$ \\
\hline 4 & 31.40938 & 30.17463 & 2.24 & 1.6 & $4.09 \mathrm{E}+01$ & $6.25 \mathrm{E}+01$ & $1.86 \mathrm{E}+01$ \\
\hline 5 & 31.4096 & 30.1645 & 2.58 & 1.2 & $4.71 \mathrm{E}+01$ & $7.19 \mathrm{E}+01$ & $2.14 \mathrm{E}+01$ \\
\hline 6 & 31.4096 & 30.1778 & 2.32 & 3 & $4.24 \mathrm{E}+01$ & $6.47 \mathrm{E}+01$ & $1.92 \mathrm{E}+01$ \\
\hline 7 & 31.4096 & 30.1783 & 1.87 & 4.2 & $3.42 \mathrm{E}+01$ & $5.21 \mathrm{E}+01$ & $1.55 \mathrm{E}+01$ \\
\hline 8 & 31.4112 & 30.1825 & 2.65 & 2.3 & $4.84 \mathrm{E}+01$ & $7.39 \mathrm{E}+01$ & $2.19 \mathrm{E}+01$ \\
\hline 9 & 31.4117 & 30.1624 & 2.4 & 1.57 & $4.39 \mathrm{E}+01$ & $6.69 \mathrm{E}+01$ & $1.99 \mathrm{E}+01$ \\
\hline 10 & 31.4137 & 30.1672 & 3.25 & 6.5 & $5.94 \mathrm{E}+01$ & $9.06 \mathrm{E}+01$ & $2.69 \mathrm{E}+01$ \\
\hline 11 & 31.4139 & 30.1582 & 1.76 & 5.5 & $3.22 \mathrm{E}+01$ & $4.91 \mathrm{E}+01$ & $1.46 \mathrm{E}+01$ \\
\hline 12 & 31.4156 & 30.1574 & 1.65 & 2.3 & $3.01 \mathrm{E}+01$ & $4.60 \mathrm{E}+01$ & $1.37 \mathrm{E}+01$ \\
\hline 13 & 31.4178 & 30.1772 & 1.46 & 1.9 & $2.67 \mathrm{E}+01$ & $4.07 \mathrm{E}+01$ & $1.21 \mathrm{E}+01$ \\
\hline 14 & 31.4185 & 30.172 & 2.75 & 1.66 & $5.02 \mathrm{E}+01$ & $7.67 \mathrm{E}+01$ & $2.28 \mathrm{E}+01$ \\
\hline 15 & 31.41965 & 30.15673 & 2.52 & 1.4 & $4.60 \mathrm{E}+01$ & $7.03 \mathrm{E}+01$ & $2.09 \mathrm{E}+01$ \\
\hline 16 & 31.4205 & 30.188 & 3.1 & 4.4 & $5.66 \mathrm{E}+01$ & $8.64 \mathrm{E}+01$ & $2.57 \mathrm{E}+01$ \\
\hline 17 & 31.4215 & 30.1756 & 2.75 & 1.3 & $5.02 \mathrm{E}+01$ & $7.67 \mathrm{E}+01$ & $2.28 \mathrm{E}+01$ \\
\hline 18 & 31.4215 & 30.188 & 3.15 & 1.79 & $5.76 \mathrm{E}+01$ & $8.78 \mathrm{E}+01$ & $2.61 \mathrm{E}+01$ \\
\hline 19 & 31.4226 & 30.1686 & 3.33 & 2.4 & $6.08 \mathrm{E}+01$ & $9.28 \mathrm{E}+01$ & $2.76 \mathrm{E}+01$ \\
\hline 20 & 31.4242 & 30.1565 & 3 & 2.22 & $5.48 \mathrm{E}+01$ & $8.36 \mathrm{E}+01$ & $2.48 \mathrm{E}+01$ \\
\hline 21 & 31.425 & 30.1558 & 1.67 & 1.5 & $3.05 \mathrm{E}+01$ & $4.66 \mathrm{E}+01$ & $1.38 \mathrm{E}+01$ \\
\hline 22 & 31.425 & 30.1776 & 2.75 & 4.3 & $5.02 \mathrm{E}+01$ & $7.67 \mathrm{E}+01$ & $2.28 \mathrm{E}+01$ \\
\hline 23 & 31.4361 & 30.1688 & 2.61 & 1.7 & $4.77 \mathrm{E}+01$ & $7.28 \mathrm{E}+01$ & $2.16 \mathrm{E}+01$ \\
\hline 24 & 31.43656 & 30.15105 & 1.64 & 2.1 & $3.00 \mathrm{E}+01$ & $4.57 \mathrm{E}+01$ & $1.36 \mathrm{E}+01$ \\
\hline 25 & 31.4373 & 30.1722 & 2.33 & 2.3 & $4.20 \mathrm{E}+01$ & $6.41 \mathrm{E}+01$ & $1.91 \mathrm{E}+01$ \\
\hline 26 & 31.4389 & 30.16055 & 2.74 & 3.8 & $5.01 \mathrm{E}+01$ & $7.64 \mathrm{E}+01$ & $2.27 \mathrm{E}+01$ \\
\hline 27 & 31.444 & 30.1701 & 2.24 & 2.1 & $4.09 \mathrm{E}+01$ & $6.25 \mathrm{E}+01$ & $1.86 \mathrm{E}+01$ \\
\hline
\end{tabular}

using MATLAB code which was created for this purpose. The presence of deep sedimentary basin in the studied area suggests that the site response should be important. Consequently, the obtained fundamental frequency has lower values $(1-8 \mathrm{~Hz})$. However, low frequency ground motions attenuate more gradually with distance and can excite vibrations in large engineered structures, such as tall buildings and long bridges.

The microtremor measurements were carried out at 27 sites (Fig. 1) distributed within the area of interest. These measurements were acquired using high sensitivity seismometers of Trillium - 40 equipped with threecomponent digital seismograph data logger (Taurus model of NANOMETRICS): two horizontal motions (in longitudinal and transverse directions) and one vertical motion. These noise measurements were recorded for $60 \mathrm{~min}$ of continuous recording at every site with sampling rate of $100 \mathrm{~Hz}$. Some of these measurements were repeated during the night to minimize artificial noises due to traffic and human activities.
The recorded data have been processed in relevance to the following procedures; base line and instrumental correction; band-pass filtering to define the optimum frequency range $(0.2-10 \mathrm{~Hz})$; the time windows length of $70 \mathrm{~s}$ length were automatically selected; cosines type window tapering on $5 \%$ of the signal were applied; Fourier spectra of the three components (NS, EW, Z) were calculated; calculated Fourier spectra of the three components were smoothed; the horizontal components were merged by geometric mean (sqrt; spec $\mathrm{EW}^{*}{ }^{*}$ spec NS); the H/V spectral ratios were calculated by dividing the spectra of the merged horizontal components to the spectra of the vertical component. The resulted values of fundamental frequency $\left(F_{0}\right)$ and the corresponding amplification factor $\left(A_{0}\right)$ at every site are estimated. The peaks of $\mathrm{H} / \mathrm{V}$ curves of artificial origin due to traffic and human activities are detected, checked, and ignored from H/V spectral ratio calculations. It is noticed that, the selection of time window length depends mainly on the noise level stability and the interested frequencies at every site. Long time window is preferred because it allows more stable spectral windows 
for noise (Parolai et al., 2004). Hence, the number of stable windows could be varying from one site to another within the area but it was greater than 10 windows.

Previous results suggest that the $\mathrm{H} / \mathrm{V}$ technique is very effective in determining the fundamental frequency at the site of interest, while it gives the lower bound of the amplification at that site. It is noticed that, $F_{0}$ values ranges from 1 to $8 \mathrm{~Hz}$. These low values reflect the thick section of soft sediments (fine sands and sabkha) prevailing at the area. The obtained results from background noise are in strongly agreement with the obtained results from boreholes data. The PGA values obtained form the synthetic ground motion model using regional seismotectonic parameters vary from $12 \mathrm{gal}$ to 96 gal (Table 4). The site No. 2 gives the highest PGA value of $96 \mathrm{gal}$ by taking hypocentral distance of $7.7 \mathrm{~km}$.

\section{Validation of the model parameters}

One important step of our analysis includes the validation of the stochastic model parameters at the free-field station that recorded the earthquake and the one derived in the present study which was based on the geometric spreading function for eastern North America derived by Atkinson and Boore (1995). To verify its applicability for Egypt, Abd El-Aal (2010) compared recorded PGA and simulated PGA computed with the used stochastic method for a significant earthquake. On 24 August 2002, at 23:01 local time, one significant earthquake in greater Cairo occurred, its magnitude was $M_{\mathrm{b}}=4.3$, focal coordinates were $30.14^{\circ} \mathrm{N}, 31.35^{\circ} \mathrm{E}$ and focal depth was $19 \mathrm{~km}$. The earthquake was felt over a very large area. This event was recorded by strong ground motion stations. Abd El-Aal (2010) simulated the event at location of the station, namely TURA, where strong motion instruments exist, taking into consideration the local site condition of the station. The station was located at coordinates $29.93^{\circ} \mathrm{N}$ and $31.33^{\circ} \mathrm{E}$ on a limestone hard rock. The recorded and simulated PGAs at that station resulting form this earthquake were $2.25 \mathrm{gal}\left(\mathrm{cm} / \mathrm{s}^{2}\right)$ and $2.23 \mathrm{gal}\left(\mathrm{cm} / \mathrm{s}^{2}\right)$, respectively. Comparisons are made for horizontal-component peak ground accelerations. The observed motions are in reasonable agreement with the predictions where no amplification or at least very small observed. This is due to the location of station amplification is sited on hard rock. It was found a big similarity between recorded and simulated values. In general, the local match between synthetic computations and the few observations available for the 24 August 2002 earthquake encourages the extension of the applicability of our calculations to the rest of the area, where no surveys or observations are available.

Immediately after the 24 August 2002 earthquake, National Research Institute of Astronomy and Geophysics (2002) announced the effect and damages and recorded PGA related to this event in a technical report submitted to the Egyptian Government. Critical to these estimates is estab- lishing the similarities/differences between the TURA site (for example), where records of the mainshock exist, and the investigated sites, where there are no mainshock records but where several buildings collapsed during the earthquake. Models based on natural noise measurements and lithologies are compared at the two sites (recorded and investigated sites). Below $15 \mathrm{~m}$ depth, the sites are nearly identical from a seismic response perspective. Abd El-Aal (2010) concluded, however, that the ground motions were probably higher at the investigated sites than at the TURA site (hard rock), particularly in the range of periods from 0.1 to $1.0 \mathrm{~s}$, and that this difference is mainly due to the softer sediments (higher $S$ slowness) in the upper $15 \mathrm{~m}$ at studied sites. A correction to the acceleration map reported by National Research Institute of Astronomy and Geophysics (2002) is essentially required for the whole Greater Cairo Area, taking into consideration the site amplification factors, because the strong ground motion instruments are sited at hard rock sites in and around the greater Cairo where the amplification is negligible in comparison to the soft sites. For more details about this study, refer to the work of Abd El-Aal (2010).

Generally, amplifications in simulations of rock sites are assumed to be equal to one. However, it is hard to accept the rock sites, at which the 24 August 2002 earthquake was recorded by strong ground motion stations in and around greater Cairo, are representative of the studied area. At such sites, the seismic motions are amplified due to the presence of fractured structure and thin weathered layers. As seen in Table 4, the amplification values for the investigated sites are about 3.45 up to $6.5 \mathrm{~Hz}$, and at higher frequencies, the values change into de-amplification due to the high near surface attenuation.

\section{Results and discussion}

The fundamental frequency, site amplification, PGA, and pseudo spectral acceleration at the northeastern part of greater Cairo from the effective three different seismogenic zones in and around the area of interest, have been estimated (Table 4). The estimated motions are based on correcting motions recorded during the mainshock of 24 August 2002, $7.7 \mathrm{~km}$ from the investigated sites for the relative site response of the sites. Shear-wave slownesses and damping based on analysis of background noise measurements at the investigated sites were used in the site response analysis. It was estimated that the motions at the studied sites were probably larger, by factors ranging from 1.46 to 3.45 , than that computed and illustrated by National Research Institute of Astronomy and Geophysics (2002).

Representative examples of the simulated PGA predicted from different seismic sources at the surface at the location of largest and lowest amplification sites are shown in Fig. 9. The results reflect clearly the effect of local site conditions upon the predicted ground motion. The spatial distribution 

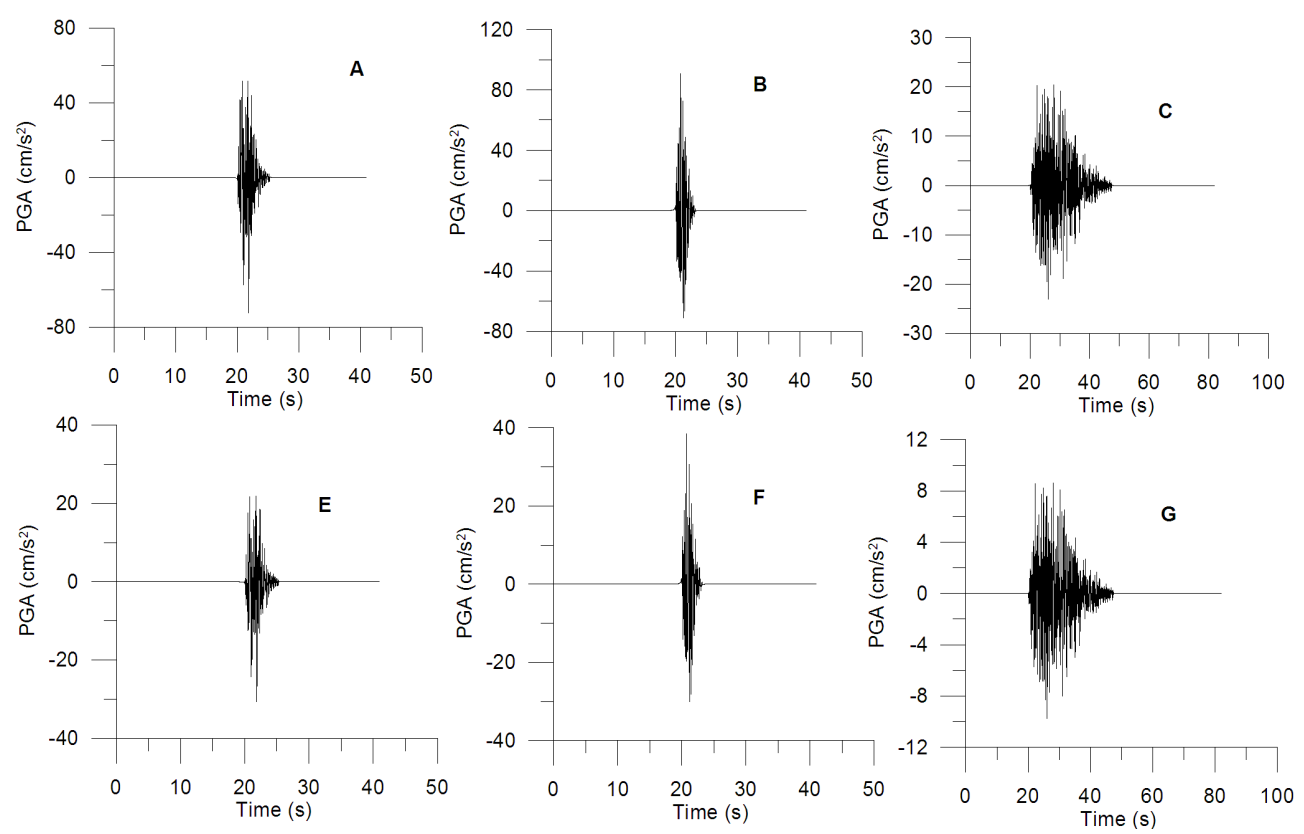

Fig. 9. Panels A, B, and $\mathbf{C}$ are the simulated PGA predicted from seismogenic zones 1, 2 , and 3 at the highest amplification site (site 2), respectively. Panels $\mathbf{E}, \mathbf{F}$, and $\mathbf{G}$ are the simulated PGA predicted from the seismogenic zones 1, 2 and 3 at the lowest amplification site (site 13).
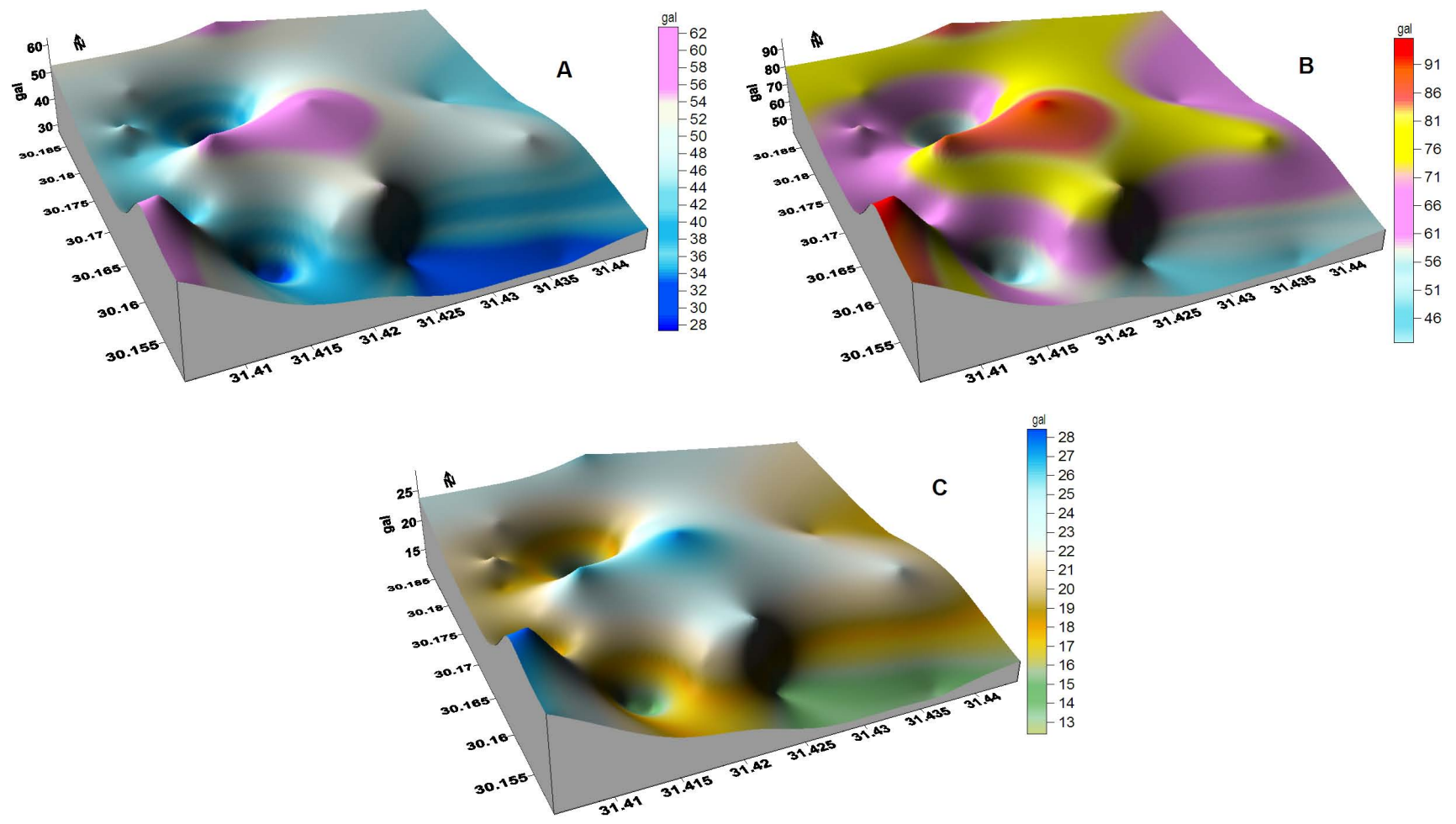

Fig. 10. Surface maps show the peak ground accelerations (PGAs), in the area of interest, predicted from the different seismogenic zones. Panel A from seismogenic zone 1 (Abou Zabul zone), panel B from the seismogenic zone 2 (southeast Cairo trend) and panel $\mathbf{C}$ from the seismogenic zone 3 (Dahshour seismogenic zone). 

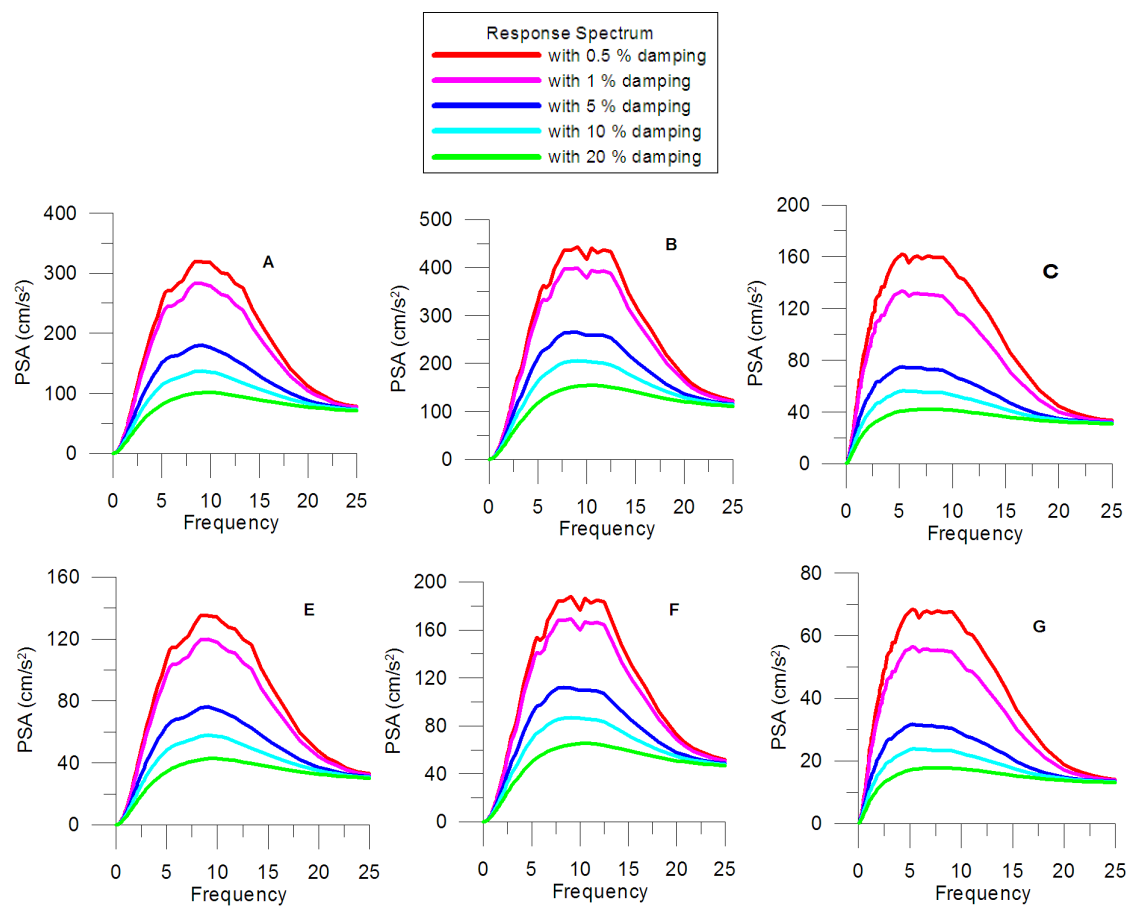

Fig. 11. Panels A, B, and $\mathbf{C}$ are the PSA predicted from the seismogenic zones 1, 2, and 3 at the high amplification site (site 2), respectively. Panels $\mathbf{E}, \mathbf{F}$, and $\mathbf{G}$ are the PSA predicted from the seismogenic zones 1, 2, and 3 at the low amplification site (site 13).

of PGA (Fig. 10) due to sources located at an epicentral distance of 13.2, 7.7, and $46.2 \mathrm{~km}$ at most shows that the highest accelerations are concentrated in soft soil sites. The hazard maps denote ground motion on surface; thus, the current analysis considers the amplification of soils or basins responses. These factors can change the ground motions and should be considered in the analysis of any site with ground conditions different from rock.

The pseudo spectral acceleration (PSA) is an important characterization of seismic ground motion in earthquake engineering. Response spectra are defined on the basis of the response of a single degree of freedom damped oscillator to the earthquake acceleration (Jennings, 1983). The response spectra of an accelerogram serve a two-fold function characterizing the ground motion as a function of frequency and providing a tool for determining earthquake resistant design criteria. The response spectrum $(0.5 \%, 1 \%, 5 \%, 10 \%$, and $20 \%$ damped pseudo-acceleration) for frequencies of 0.1 to $25 \mathrm{~Hz}$ was simulated for the effective seismic sources in and around studied area at high and low amplification sites in the area (Fig. 11). The presented results could be used as a basis for design motion specification of critical structure and for the nonlinear analysis (structural, site response, landslides, and liquefaction).

Earthquakes that are located within a circle of $100 \mathrm{~km}$ around the studied area can generate ground acceleration up to 64, 96, and 29 gal (V-VI, VI-VII and IV-V, MSK) in the highly populated area within the studied area respec- tively. These values are rather high for the existing built environment and could cause severe damage and huge socioeconomic losses due to the great economic importance of the area. Distant earthquakes, located as far away as the Gulf of Aqaba, Cyprus and Crete $(200 \pm 800 \mathrm{~km})$, can generate ground acceleration up to $20 \mathrm{gal}$ (IV) in the area of our interest. The energy in this case is carried by long-period surface waves that would be a source of danger mainly for tall buildings, long bridges and lifelines.

From an engineering point of view, infrastructure designing is interested in the frequency range $1-10 \mathrm{~Hz}$. So the high ground motion amplification factors at that frequency range play an important role in the seismic disasters. In order to mitigate the seismic risk (earthquake damages) the influence of the site effects (ground motion amplification factor and its corresponding resonance frequency) should be taken into account during the construction.

\section{Conclusions}

The importance of the Greater Cairo Area is due to the dense population and it is extending towards the seismic sources. The investigated area is characterized by low to moderate seismic activity and was affected by some felt and damaging historical and instrumental earthquakes. To assess the seismic hazard a deterministic seismic approach followed by stochastic PGA simulation was used. The deterministic seismic hazard assessment in the current study provides 
a quantitative evaluation of the nature of ground shaking at the investigated area that could be induced by future maximum earthquakes, in order to provide the engineers and planners with complete information on which they must base their decisions. For this purpose, the effective seismogenic zones around the studied area, $M_{\max }$, the path and site effects were essentially taken into consideration during calculations. Then, the shear wave excitation from nearest seismogenic zones to the northeastern part of the greater Cairo, utilizing stochastic method, was simulated. The stochastic method was applied to simulate expected acceleration records from different effective seismogenic zones around the investigated area and to assess the distribution of ground motion within the meizoseismal area of the 24 August 2002 earthquake, where no records are available. The sedimentary basin, in which the investigated area is located in, focuses and amplifies the seismic waves as they pass through. The impedance contrast controls the amount of wavefield amplification within the basin. Reverberation of S-waves within the basin lead to a long duration and a large coda amplitude. It was demonstrated that the ground motion will be considerably amplified by the soil layer and this must be taken into consideration during the construction of the buildings. It was concluded that large modifications of seismic waves are due to variations of material properties near the Earth's surface and by both surface and buried topography. The resulted hazard maps are essential for developing useful public policy that may influence land-use planning, building regulations, insurance rate assessment and emergency preparedness.

Acknowledgements. The author is grateful to National Research Institute of Astronomy and Geophysics (NRIAG). The author is also greatly indebted to the Egyptian General Organization for Physical Planning for providing maps, boreholes data and all the useful data sets. The manuscript is highly improved by the suggestions that were given by the reviewers.

Edited by: M. E. Contadakis

Reviewed by: R. Carbonell, G. Karakaisis, and I. Kalogeras

\section{References}

Abd El-AaL, A. K.: Simulating Time-Histories and PseudoSpectral Accelerations from the 1992 Cairo Earthquake at the Proposed El-Fayoum New City Site Egypt, Acta Geophys., 56, 1025-1042, doi:10.2478/s11600-008-0054-6, 2008.

Abd El-AaL, A. K.: Modeling of seismic hazard at the northeastern part of greater Cairo metropolitan area, Egypt, J. Geophys. Eng., 7, 75-90, doi:10.1088/1742-2132/7/1/007, 2010.

Abdel-Fattah, A. K. and Badawy, A.: Source characteristics and tectonic implications of moderate earthquake, northeastern Cairo prefecture, Acta Geophys. Pol., 52, 29-43, 2004.

Abou Elenean, K. M.: A study of the seismotectonics of Egypt and relation to the Mediterranean and Red Seas tectonics, Ph.D. thesis, Faculty of Science, Ain Shams University, Egypt, 1997.
Abou Elenean, K. M. and Hussein, H. M.: The October 11, 1999 and November 08, 2006 Beni Suef earthquakes, Egypt, Pure Appl. Geophys., 165, 1391-410, 2008.

Abou Elenean, K. M., Mohamed, A. E., and Hussein, H. M.: Source parameters and ground motion of the Suez-Cairo shear zone earthquakes, Eastern Desert, Egypt, Nat. Hazards, 52, 431-451, 2010.

Acharya, H. K.: Regional variations in the rupture-length magnitude relationships and their dynamical significance, B. Seismol. Soc. Am., 69, 2063-2084, 1979.

Aki, K.: Local site effects on strong ground motion, Proc. Earthquake Eng. Soil Dyn. II, 103-155, 1988.

Atkinson, G. M. and Boore, D. M.: Ground motion relations for eastern North America, B. Seismol. Soc. Am., 85, 17-30, 1995.

Badawy, A.: Status of the crustal stress as inferred from earthquake focal mechanisms and borehole breakouts in Egypt, Tectonophysics, 343, 49-61, 2001.

Bonilla, M. G., Mark, R. K., and Lienkaemper, J. J.: Statistical relations among earthquake magnitude, surface rupture length, surface rupture displacement, B. Seismol. Soc. Am., 74, 2379411, 1984.

Borcherdt, R. D.: Effects of local geology on ground motion near San Francisco Bay, B. Seismol. Soc. Am., 60, 29-61, 1970.

Boore, D. M.: Stochastic simulation of high frequency ground motions based on seismological models of the radiated spectra, B. Seismol. Soc. Am., 73, 1865-1894, 1983.

Boore, D. M.: Prediction of ground motion using the stochastic method, Pure Appl. Geophys., 160, 635-676, 2003.

Brune, J. N.: Tectonic stress and the spectra of seismic shear waves from earthquakes, J. Geophys. Res., 75, 4997-5009, 1970.

Brune, J. N.: Correction, J. Geophys. Res., 76(20), 5002, doi:10.1029/JB076i020p05002, 1971.

Coppersmith, K. J.: Seismic source characterization for engineering seismic hazard analysis, in: Proc. 4th International Conference on Seismic Zonation, Vol. I, Earthquake Engineering Research Institute, Oakland, California, 3-60, 1991.

Daggett, P. H., Morgan, p., Boulos, F. K., Hennin, S. F., El Sherif, A. A., El Sayed, A. A., Basta, N. Z., and Melek, Y. S.: Seismicity and active tectonics of the Egyptian Red Sea margine and the northern Red Sea, Tectonophysics, 125, 313-324, 1986.

EGSMA: Geological map of greater Cairo area with scale 1:100 000, Egyptian Geological Survey and Mining Authority, 1983.

El Hadidy, S.: Crustal structure and its related causative tectonics in Northern Egypt using geophysical data, Ph.D. thesis, Ain Shams University Cairo, Egypt, 1995.

Field, E. H., Jacob, K. H., and Hough, S. H.: Earthquake site response estimation, a weak-motion case study, B. Seismol. Soc. Am., 82, 2283-2307, 1992.

Field, E. H. and Jacob, K. H.: The theoretical response of sedimentary layers to ambient seismic noise, Geophys. Res. Lett., 20, 2925-2928, 1993.

Fukao, Y. and Kikuchi, M.: Source retrieval for mantel earthquakes by iterative deconvolution of long-period P-wave, Tectonophysics, 144, 249-269, 1987.

Hanks, T. C. and Kanamori, H.: A moment-magnitude scale, J. Geophys. Res., 84, 2348-2350, 1979.

Hanks, T. C. and Wyss, M.: the use of body-wave spectra in the determination of seismic-source parameters, B. Seismol. Soc. Am., 
62, 561-589, 1972.

Hanks, T. C. and Bakun, W. H.: A bilinear source-scaling model or M-logA observations of continental earthquakes, B. Seismol. Soc. Am., 92, 1841-6, 2002.

Japanese Expert Team: Report of Japan Disaster Relief Team on the earthquake in Arab Republic of Egypt of October 12, 1992, 1993.

Jennings, P. C.: Engineering seismology, in: Proceedings of the International School of Physics "Enrico Fermi", Course LXXXV, edited by: Kanamori, H. and Boschi, E., 138-173, 1983.

Kanai, K.: The requisite conditions for predominant vibration of ground, B. Earthquake Res. Inst. Tokyo Univ., 31, p. 457, 1957.

Kebeasy, R. M.: Seismicity of Egypt, in: Geology of Egypt, edited by: Said, R., A. A. Balkema, Rotterdam, 51-59, 1990.

Kijko, A.: Estimation of the maximum earthquake magnitude, $m_{\text {max }}$, Pure Appl. Geophys., 161, 1655-81, 2004.

Maamoun, M. and Allam, A.: A study of the seismicity of the east Mediterranean region, 7th Ann. Meet., EGS-ESC, Budapest, 1980.

Maamoun, M., Megahed, A., and Allam, A.: Seismicity of Egypt, B. Helwan Inst. Ast. Geophys., 4, 109-160, 1984.

Moustafa, S.: Assessment of ground motion variation for seismic hazard mitigation in the vicinity of Cairo metropolitan area, Ph.D. thesis, Ain Shams Univ. Cairo, Egypt, 2002.

Nakamura, Y.: A method for dynamic characteristics estimation of subsurface using microtremor on the ground surface, Quarterly Report of RTRI, 30-1, 25-33, 1989.

National Research Institute of Astronomy and Geophysics: Technical report for August 24, 2002 Cairo earthquake, Internal report submitted to Egyptian Government and Egyptian Ministry of Housing, Utilities and Urban Communities, 2002.

Ohnaka, M.: Earthquake-source parameters related to magnitude, Geophys. J. Roy. Astr. S., 55, 45-66, 1978.
Parolai, S., Bindi, D., Boumbach, M., Grosser, H., Milkereit, C., Karakisa, S., and Zünbül, S.: Comparison of different site response estimation techniques using aftershocks of the 1999 Izmit earthquake, B. Seismol. Soc. Am., 94, 1096-1108, 2004.

Reiter, L.: Earthquake Hazard Analysis, New York: Columbia University Press, 254 pp., 1991.

Said, R.: The geology of Egypt, Elsevier Publication Amsterdam, 1990.

Schwartz, D. P.: Geology and seismic hazards: moving into the 1990's, in: Earthquake Engineering Soil Dynamics II - Recent Advances in Ground Motion Evaluation, edited by: Van Thun, J. L., American Society of Civil Engineers Geotechnical Special Publication, New York, 20, 1-42, 1988.

Schwartz, D. P. and Coppersmith, K. J.: Seismic hazards-new trends in analysis using geologic data, in Active Tectonics, National Academy Press, Washington, DC, 215-230, 1986.

Slemmons, D. B.: State of the art for assessing earthquake hazard in the United States, in: Report 6 - Faults and earthquake magnitude, US Army Corps of Engineers, Waterways Experiment Station, Vicksburg, Mississippi, Miscellaneous Paper, S73-1, 129 pp., 1977.

Slemmons, D. B.: Determination of design earthquake magnitudes for microzonation, in: Proc. of the Third International Earthquake Microzonation Conf., US National Science Foundation, Washington, DC, 1, 119-130, 1982.

Slemmons, D. B., Bodin, P., and Zang, X.: Determination of earthquake size from surface faulting events, Proc. of the International Seminar on Seismic Zonation, Guangzhou, China, State Seismological Bureau, Beijing, 13, 1989.

Wells, D. L. and Coppersmith, K. J.: New empirical relationships among magnitude, rupture length, rupture width, rupture area, and surface displacement, B. Seismol. Soc. Am., 84, 974-1002, 1994. 